TAPROBANICA, ISSN 1800-427X. April, 2009. Vol. 01, No. 01: pp. 55-62, pls 8.

(C) Taprobanica Nature Conservation Society, 146, Kendalanda, Homagama, Sri Lanka.

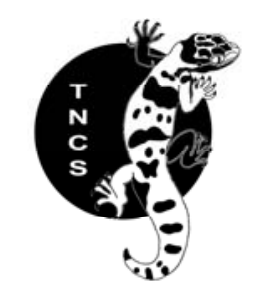

\title{
THE WILD BUFFALO OF SRI LANKA
}

Submitted: 20 February 2009, Accepted: 26 February 2009

\section{Colin Groves ${ }^{1}$ and Jayantha Jayawardene ${ }^{2}$}

\footnotetext{
${ }^{1}$ School of Archaeology \& Anthropology, Australian National University, Canberra, ACT 0200, Australia

${ }^{2}$ Biodiversity and Elephant Conservation Trust, 615/32, Rajagiriya Gardens, Rajagiriya, Sri Lanka.

${ }^{1}$ Corresponding author: colin.groves@anu.edu.au
}

\begin{abstract}
Buffaloes live wild in many areas in Sri Lanka, but it is controversial whether any of them are genuinely wild, or whether they are all feral. We investigated this question by observation of living buffaloes in Yala National Park, and measurement of available cranial material. We conclude that there is indeed an indigenous wild buffalo in Sri Lanka. Steps should be taken to ensure its genetic integrity.
\end{abstract}

Key Words: Buffalo, Bubalus arnee migona, Sri Lanka, Yala, cranial capacity.

\section{Introduction}

Does Sri Lanka have a native wild buffalo?

$19^{\text {th }}$-century authors, such as Kelaart, listed the Sri Lankan wild buffalo as a genuinely wild animal, and Deraniyagala (1952, amplified in 1953) described it as a separate subspecies. More recent authors, however, have either assumed it to be of feral origin (Ellerman \& Morrison-Scott, 1951; Phillips, 1980), or have suspended judgment.

Eisenberg \& McKay (1970) wrote "status of feral population is debatable"; while Ashby \& Santiapillai (1983) remarked, "Given the distinctiveness of the free-living form in Sri Lanka, the balance of probability is that it should be regarded as wild rather than feral but no conclusive answer can be given on the present evidence".

Wherever there are wild buffalo, there is a danger of interbreeding with local domestic stock. The truly wild buffalo of the Asian mainland are all notably larger than any local domestic buffaloes, and it would not be expected that feral or mixed buffaloes would offer them much competition; consequently, feral buffaloes would have little chance of surviving for long, and gene-flow would be almost entirely one-way (from wild to domestic). If on the other hand the genuine wild stock becomes numerically depleted, competition would be relaxed, and there 
would be an opportunity for feral populations to become established with the resulting influx of domestic genes into the remnant wild population. Under such conditions, it might be difficult to disentangle unmixed from mixed stock within a wild population.

This problem was faced by Heinen (2002) in the case of the buffalo of Kosi Tappu Reserve, in Nepal. The domestic stock in the surrounding area are so-called River Buffaloes, which with their solid black colour and small, spirally curled horns are strikingly different from the wild buffaloes in the Reserve. But in the past the wild buffaloes have been persecuted, and rather few remain, so there is a problem of sorting out the mixtures. Heinen (2002) gave criteria for differentiating wild from backcrosses; among these are behavioural differences - wild herds are cohesive and consist of a single bull with a small group of cows and calves, while backcrossed herds are much more variable, and often lack bulls. Later genetic analysis (Flamand et al., 2003) seems to have corroborated Heinen's conclusions.

There could well be a similar problem in Sri Lanka, where a rinderpest epidemic in the early $20^{\text {th }}$ century almost wiped out the wild buffaloes (Phillips, 1980). Whether they support the idea of a truly wild stock or not, all recent authors have agreed that there is a problem of feral and backcross stock. For example Deraniyagala (1955) acknowledged that by the time of his writing most of the wild herds had become intermixed: "The relatively purest herds are restricted to Yala Game sanctuary, but much vigilance will be necessary if this remnant is to be kept free from domestic animals which are now encroaching upon this once inaccessible area".

The domestic buffaloes of Sri Lanka are reputed to be Swamp Buffaloes; this domestic type, otherwise restricted to Southeast and East Asia, is very different in appearance from the River Buffalo breeds of South Asia, being grey or grey-brown, marked with white on the lower legs, throat and face, and with crescentic horns more resembling the wild buffalo. If this is the case, then interbreeding would be much more difficult to detect than with the River Buffaloes of Nepal. River and Swamp buffaloes have different chromosome numbers: $2 \mathrm{n}=$ 50 in River but 48 in Swamp buffaloes; in fact Sri Lankan buffaloes, despite their external resemblance to Swamp buffaloes, have a diploid number of 50 like River breeds (Bongso et al., 1977).
The purpose of this study is to try to determine whether there is indeed a genuine wild buffalo in Sri Lanka and, if so, what relationship it bears to those of the mainland of Asia as revised by Groves (1996).

\section{Material and methods}

We studied skulls of wild and domestic buffaloes in several collections; most of these are listed in Groves (1996), but some additional material was studied in the Sri Lanka National Museum (SLNM) and in the private collection of Kelum Manamendra-Arachchi (KM-A). Measurements taken are as given in Groves (1996) and in addition cranial capacities were measured where possible. The available skulls of Sri Lankan wild buffaloes were as follows (the numbers are the sequential numbers in the analysis): (1) Locality "Ceylon":

79. CPH 1188;

83. SLNM 78G;

85. NMW 5300;

88. ZMB 32130.

(2) Locality Yala:

80. SLNM 78;

86. BM 46.210;

87. FIR 8072;

92. Yala - mounted in museum of Yala Vistors'

Centre;

94. Yala - brought in to Yala Vistors' Centre by tracker on Saturday, Aug.28, 2004;

95. Yala - brought in to Yala Vistors' Centre by tracker on Sunday, Aug. 29, 2004.

(3) Locality Gammaduwa, Knuckles Range:

89. Private collection of KM-A.

These skulls were compared, using multivariate analysis (SPSS version 12.0.1), with both wild skulls from the Asian mainland and with skulls of domestic buffaloes, including both River Buffaloes (from South Asia and Italy) and Swamp Buffaloes (from Southeast Asia). If any Sri Lankan skulls fell outside the range of the domestic skulls, this would indicate "something different", hence might be taken as evidence for the existence of a truly wild strain in Sri Lanka.

Colin Groves measured the cranial capacities of as many skulls, wild and domestic, as possible. Buffalo skulls, being large, are easily damaged; the skull of a wild buffalo would often in the past be treated as a symbol of a victory of a "brave hunter" over a dangerous adversary, and mounted on a trophy shield with its base sawn off. Even skulls not so treated are often peppered with bullet holes. 
Under such circumstances, the sample available for cranial capacity determination was small, but still worth documentation. Theory dictates that domestic representatives should have, on average, a small cranial capacity, after the absolute size of the specimen has been taken into account, compared to the wild ones (Hemmer, 1983; Herre \& Röhrs, 1990). Size-standardisation was by plotting cranial capacity (or endocranial volume: ECV) against the distance from basion to hormion, representing approximately the length of the brain-stem.

As a final step, those Sri Lankan skulls deemed to be those of truly wild buffaloes were compared with those of Asian mainland buffaloes.

We planned a visit to Yala National Park; in the event, J. Jayawardene was unable to participate but organized a visit by C. Groves in company with Mohomed M. Bahir, where as many groups of wild living buffaloes as possible were observed. Most of these were photographed, and all were briefly described and compared with the domestic buffaloes seen in the vicinity of the Park. A total of 13 groups of wild buffaloes were seen, mostly in and around waterholes in Block One of the Park.

\section{Results: wild or feral?}

Craniometry: In the Discriminant Analysis using horn measurements (Pl. 10; Fig. 1), the Sri Lankan sample fall partly within the domestic range, partly beyond it. Skull 89 falls within the domestic cluster and nos. 79 and 95 on the borders of it, but nos. 80, 85, 86, 88, 92 and 94 fall outside it. These, consequently, seem to be good candidates for consideration as genuine wild buffaloes. DF1 depends partly on size, but tip-to-tip distance does not follow the size trend; DF2 relies largely on tipto-tip, base-to-tip and total span. In the analysis using cranial measurements (Pl. 10; Fig. 2), those falling within the domestic range are nos. 80,88 and 92 ; those falling outside it, or on the edge, are nos. 85, 86, 90 and 94 . It is interesting that, although the two datasets are quite distinct except for biorbital breadth, there is considerable agreement between the analyses as to the placement of particular specimens. DF1 relies on a contrast between greatest and least occipital breadth, and on nasal length and nasal breadth. Pl. 11; Fig. 3 depicts the difference in horn shape between domestic swamp buffaloes, to which Sri Lankan domestic buffaloes bear most resemblance (but see below), and Sri Lankan wild buffaloes. Although some wild specimens fall within the domestic range, most do not. Note that even very large swamp buffaloes do not resemble Sri Lankan wild buffaloes, but continue the general domestic trend. One of the two domestic buffaloes with very low tip-to-tip values is a carabao from the Philippines; the other is a Sri Lankan domestic individual. Fig. 4 shows that, on the contrary, Sri Lankan wild buffaloes agree with swamp buffaloes in having a small base-to-tip distance (Pl. 11; Fig. 4a) and smaller span (P1. 12; Fig. 4b) compared to wild samples from the mainland. Pl. 12; Fig. 5 illustrates what is perhaps the most outstanding cranial difference between wild and domestic (swamp) buffaloes: the reduced nasal length of the latter. The Sri Lankan wild sample has long nasals, like Thailand Bubalus arnee theerapati. Pl. 13; Fig. 6 shows the reduction in cranial capacity of domestic buffaloes compared to mainland wild specimens. The skull with the highest cranial capacity - and so most likely wild Sri Lanka skull is Yala, no.94; followed by KM-A's from the Knuckles Range; the two lowest are Yala 95 and SLNM, from Yala.

Observations in and around Yala: Domestic buffaloes in Sri Lanka are reputed to resemble swamp buffaloes phenotypically (Cockrill, 1974). Their diploid chromosome number, however, is $2 \mathrm{n}=50$ like those of river buffaloes (Bongso et al., 1977) and they assort with river buffaloes in the DNA sequences of 21 microsatellites and 25 polymorphic protein-coding loci (Barker et al., 1997).

The domestic buffaloes of southern Sri Lanka, including the outskirts of Yala National Park (Pl. 17; Fig. 14) itself, were not in fact like any swamp buffaloes seen by CPG elsewhere (in China, Vietnam, Thailand and Indonesia). They appeared narrower in the body and shorter-legged than any swamp buffaloes, which are noticeably heavybodied and short-legged; in their build they were much more like river buffaloes. The horns were not flat and crescentic like swamp buffaloes, but had a distinct initial downward sweep followed by an upward curl in the distal portion especially toward the tip, not as tightly curled as in more specialised river breeds (Murrah, Italian), but very like less specialized breeds such as Pandarpuri. Colour varied from dark grey to black; swamp buffaloes are mostly dark grey, while river breeds are black. The colour pattern, however, did more resemble swamp buffaloes. Most individuals had light yellowish grey distal limb segments, grey-white muzzle and a white spot at the inner corner of each eye; most breeds of river buffaloes are unvarying black, but 
most swamp buffaloes are dark grey with prominently grey-white distal limb segments and white marks on the face and throat. A feature that we have not seen in any domestic buffaloes elsewhere was a thick mat of medium brown hair, contrasting with the general body colour, on the forehead between the horns, and extending back as a short crest along the nape to the withers where it would form a tuft.

Wild buffaloes are very numerous in Yala Block 1; in the heat of the day, every water-hole is full of them. Most of those seen were very like the domestic ones, and so undoubtedly feral; in fact, a ranger affirmed that actual domestic animals often move into the Park and spend the day soaking, but move back to the salt-licks near the villages in the evening. As well as these clearly feral or actual domestic buffaloes, however, there was a rarer type that was quite distinctive: noticeably larger and seemingly stockier, with horns in a single plane; brownish black, with no white markings except inconspicuously along the upper lip, and lacking the brown forehead-to-withers hairs. No difference was detectable in belly or tail hair, but this could be mainly because so many of the animals seen were partly submerged. The horns had no initial downward trend, nor upward curl along their length; instead, they were in a single plane, describing an almost flat semicircle, the tips (if long enough) curving inward. All of the mature bulls that could be fully observed (P1. 17; Fig. 15), and some cows, were of this type, which we take to be the true wildtype. Some cows appeared intermediate between the two types. The difference between wild-type horns and those apparently of mixed ancestry can be seen by comparing the two cows in Pl. 17; Fig. 16. Complete counts at seven different waterholes gave groupings as follows:

Table 01: Groups of buffalo seen in Yala National Park, Block 1 (August, 2004)

\begin{tabular}{|c|c|c|c|c|c|}
\hline Group no. & $\begin{array}{c}\text { No. of } \\
\text { Individuals }\end{array}$ & Bulls & Cows & Calves & Other notes \\
\hline 1 & 04 & 01: wild-type & $\begin{array}{l}\text { 02: one was wild- } \\
\text { type; other was } \\
\text { intermediate with } \\
\text { horns } \\
\begin{array}{ll}\text { downward } & \text { bent } \\
\end{array}\end{array}$ & 01 & - \\
\hline 2 & 05 & 01: wild-type & 04: wild-type & - & - \\
\hline 3 & 08 & 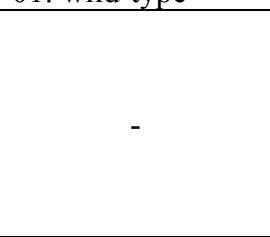 & $\begin{array}{l}\text { 06: all with very } \\
\text { long horns, rather } \\
\text { down swept in three } \\
\text { cases }\end{array}$ & $\begin{array}{l}01: \text { accompanying } \\
\text { one of the cows }\end{array}$ & $\begin{array}{l}\text { Other animal was } \\
\text { almost submerged, } \\
\text { but seemed to be a } \\
\text { bull judging by the } \\
\text { thickness of the } \\
\text { horns }\end{array}$ \\
\hline 4 & 09 & $\begin{array}{l}01: \quad \text { very large, } \\
\text { wild-type, black }\end{array}$ & $\begin{array}{l}\text { 06: grey, two with } \\
\text { very light legs and } \\
\text { one with extremely } \\
\text { long, spreading } \\
\text { horns }\end{array}$ & 02: half-grown & - \\
\hline 5 & 14 & $\begin{array}{l}\text { 05: young, with } \\
\text { short horns, one } \\
\text { having especially } \\
\text { white legs }\end{array}$ & 09: domestic-type & - & $\begin{array}{l}\text { Other animals } \\
\text { included a zebu } \\
\text { cow at this } \\
\text { waterhole, not far } \\
\text { inside the Park }\end{array}$ \\
\hline 6 & 28 & $\begin{array}{lr}01: \text { mostly } \\
\text { submerged and } \\
\text { could not be } \\
\text { clearly seen }\end{array}$ & 17 & 10 & - \\
\hline 7 & 55 & $\begin{array}{l}\text { 02: one was sub } \\
\text { adult; other was } \\
\text { an adult, which } \\
\text { could not be } \\
\text { clearly seen }\end{array}$ & $\begin{array}{l}\text { 23: mostly with } \\
\text { down and upwardly } \\
\text { curled horns, in one } \\
\text { case asymmetrical }\end{array}$ & $\begin{array}{l}\text { 30: different ages, } \\
\text { the younger ones } \\
\text { very light colored }\end{array}$ & - \\
\hline
\end{tabular}




\begin{tabular}{|c|c|c|c|c|}
\hline 8 & 04 & - & $\begin{array}{l}\text { 05: two were young; } \\
\text { three were half- } \\
\text { grown, seen in the } \\
\text { bush away from any } \\
\text { waterhole; light grey, } \\
\text { and all individuals } \\
\text { had very light legs }\end{array}$ & - \\
\hline 9 & $\begin{array}{l}\text { A large group } \\
\text { of cows and } \\
\text { calves, count } \\
\text { was not } \\
\text { possible }\end{array}$ & - & $\begin{array}{l}10<\text { of domestic-type, were on one side of a } \\
\text { waterhole (some are shown in Pl. 17; Fig. } \\
\text { 17) }\end{array}$ & $\begin{array}{l}\text { Well apart from } \\
\text { them, on the far } \\
\text { bank, was a group } \\
\text { of three }- \text { a bull } \\
\text { and a very large } \\
\text { cow, both of wild- } \\
\text { type, and another } \\
\text { cow also very } \\
\text { large but with } \\
\text { some horn curl and } \\
\text { a trace of the } \\
\text { brown nape crest } \\
\text { (Pl. 17; Fig. 16). }\end{array}$ \\
\hline
\end{tabular}

\section{Discussion: wild or feral?}

The craniometric results indicate strongly that some Sri Lankan specimens represent fully or nearly pure-bred wild buffaloes, in that they fall outside the range of variation of domestic specimens. Note that both swamp and river buffaloes are included in the domestic skull sample, but only swamp in the horn sample. Taking the results of the discriminant analyses on both skulls and horns, backed up by the bivariate scatterplots, the specimens from Sri Lanka rate as follows:

Table 02: Allocation of Sri Lankan wild-collected skulls (DR: Domestic Range)

\begin{tabular}{|l|l|l|}
\hline Locality & Catalog No. & \\
\hline \multirow{4}{*}{ "Ceylon" } & 79. CPH 1188 & at border of DR \\
\cline { 2 - 3 } & 83. NM 78G & at or beyond border of DR \\
\cline { 2 - 3 } & 85. NMW 5300 & definitely outside DR \\
\cline { 2 - 3 } & 88. ZMB 32130 & definitely outside DR \\
\hline \multirow{5}{*}{ Yala } & 80. NM 78 & at or beyond border of DR \\
\cline { 2 - 3 } & 86. BM 46.210 & definitely outside DR \\
\cline { 2 - 3 } & 87. FIR 8072 & definitely outside DR \\
\cline { 2 - 3 } & 92. Yala - mounted in museum & at border of DR \\
\cline { 2 - 3 } & 94 Yala - brought in Sunday, Aug. 29 2004 & definitely outside DR \\
\cline { 2 - 3 } & 95. Yala - brought in Sunday, Aug. 29 2004 & At border of DR \\
\hline \multirow{5}{*}{ Gammaduwa (Knuckles) } & 89. K.M-A & within DR \\
\cline { 2 - 3 } & 90. K.M-A & within DR \\
\hline
\end{tabular}

For safety's sake, therefore, only the following specimens of the Sri Lankan sample will be treated as pure-bred wild buffaloes: 85. NMW 5300; 86 . BM 46.210; 87. FIR 8072; 88. ZMB 32130; 94. Yala - Sunday, Aug. 29 2005. Others may also be "pure-bred" but, because their position was equivocal in one or more analyses, they will be treated cautiously, and excluded from the comparisons with mainland wild buffaloes.
Kelaart said that "the wild buffalo is of a darker colour and more hairy than the domesticated variety" (Kelaart 1852). Deraniyagala (1952), in the course of describing the Sri Lankan wild buffalo as a subspecies separate from that of India, listed some differences between it and the domestic buffaloes of Sri Lanka, as follows: "The wild Ceylon form is larger and stands higher in the leg, with reddish brown hair. Its horns are stronger, longer and more erect, with their tips tending more 
forwards than in the domestic form... The neck of the adult male is also more developed" (Deraniyagala 1952).

It will be seen that, once the obvious feral and backcrossed animals are excluded, a distinctive and homogeneous morphology does remain (see photo in Buchholtz, 1988:372-3). As described by Kelaart (1852) and Deraniyagala (1952), animals of this description, i.e. that are outside the phenotypic range of the domestic ones, are indeed larger and darker, but they cannot be described as reddish brown, nor as more hairy - note however that Kelaart was resident at Nuwara Eliya, and wild buffaloes at this altitude might indeed be (or have been) more hairy. The horns of the wild stock are flatly crescentic (in a single plane), but not necessarily more erect, unless by this Deraniyagala (1952) meant to contrast the shape with the initial downsweep of most domestic animals; if the tips tend more forwards, it is because they are generally longer, and so describe more of a semicircle. These conclusions are similar to those of Heinen (2002), who had much the same problem of distinguishing wild from feral and backcrossed buffaloes in Nepal; Nepalese domestic buffaloes, however, are of more strongly specialized river type, so their differences from wild ones are more clear-cut - for all that Sri Lankan domestics are of river stock, not swamp, they are primitive, which is doubtless why Cockrill (1972) deemed them to be swamp buffaloes. Heinen's criteria were tested by Flamand et al. (2003), using several genetic loci; they were able to allocate wild vs. feral and backcrossed animals with a high degree of success.

Heinen (2002) makes the point that wild herds have a definite social structure, of cows and calves with a herd bull, the members of the herd being always in close proximity; while feral/backcrossed groups were very variable in size and composition, and were often without herd bulls. The same features seem to distinguish wild from feral/backcrossed groups around the waterholes of Yala. We interpret the groups described earlier as follows: group 2: evidently a pure-bred wild herd; group 1: a wild bull with one wild cow, one backcrossed cow; group 4: a wild bull with feral cows; groups 3, 6, 7: the bull unclear, the cows largely backcrossed or feral; group 5: an entirely feral grouping. The "final group", mentioned in the right-hand column of group 9, appears to be a social herd of 3 pure-bred (one bull, two cows), keeping separate from a feral/backcrossed conglomerate.
Results: wild buffalo from Sri Lanka vs. mainland: How does the Sri Lankan wild buffalo relate to the three mainland subspecies described by Groves (1996)? Is it a fourth subspecies of Bubalus arnee, or should it be ranked as a distinct species? It is also presumably possible, though not at all likely, that it represents one of the mainland subspecies, introduced in the distant past to Sri Lanka.

Deraniyagala (1952) briefly gave the name Bubalus bubalis migona to the Sri Lankan wild buffalo, with the type a mounted head No. $78 \mathrm{~B}$, in the Colombo museum. For this specimen (not found in my visits of 2003 and 2004) the museum catalogue gives a tip-to-tip distance of 2 feet, 7 inches $(789.5 \mathrm{~mm})$, which is within the range of specimens measured by CPG. He gave the type locality of his new subspecies as Yala; the catalogue however lists no locality for the specimen. In the following year Deraniyagala (1953) compared to his new subspecies more specifically with the Indian wild buffalo: the horns, he stated, are relatively shorter and curve more forward towards their tips. In what follows, the name migona will applied to the Sri Lankan wild buffalo without prejudice to what its ultimate taxonomic status may be.

The horns of wild buffaloes can be sexed by the basal diameter of the sheaths. As Pl. 13; Fig. 7 shows, the degree of sexual dimorphism is about equivalent in all four putative subspecies (note that CPG has reallocated the sex of some specimens of B. a. theerapati from Groves, 1996). To judge from those in specimens which both sheath and core could be measured, the core diameter is about 10 $\mathrm{mm}$ less than that of the sheath. Not many domestic specimens in the sample had the sexes recorded, but no bimodality in basal diameter is apparent, so it may be that this is one further character in which domestic buffaloes differs from wild. The horns of Sri Lankan buffaloes average smaller in all dimensions than those from the mainland; the distance from base to tip is shown in Pl. 14; Fig. 8, and horn span in Pl. 14; Fig. 9.

The skulls of both migona and theerapati are noticeably smaller than those of arnee and fulvus, and unlike the latter the sexes are the same size $(\mathrm{Pl}$. 15; Fig. 10). In the case of the greatest occipital breadth, however, migona is smaller than theerapati, and unique in its lack of sexual dimorphism (Pl. 15; Fig. 11). The narrower occiput may relate to the relatively small horns of migona. 
Pl. 16; Fig. 12 shows a discriminant analysis of three cranial measurements (one of the five available skulls lacks the other measurements). In this admittedly limited comparison, migona overlaps with both arnee and theerapati, but is overall closer to the latter. In Pl. 16; Fig. 13, four horn measurements are used; here, the separation of migona is somewhat greater, only one of the specimens being within the ranges of the mainland samples.

We may conclude that, on the data so far available, the skulls and horns of migona differ on average from those of mainland Bubalus arnee, but not absolutely. It may be different in the case of external characters. Among the ways in which the wild buffalo of Yala differ from domestic buffalo is the virtual absence of white markings. All photographs of mainland $B$. arnee show conspicuous grayish or yellowish white limbs, from the knees and hocks to the hoofs, white gorgets (one or two transverse crescents on the throat), and white spots on the lower face. It may be, therefore, that in this respect the Sri Lankan form is absolutely different from the mainland ones. If this is really the case, then it would be appropriate to recognize it as a distinct species (under the so-called Phylogenetic Species Concept, a species has fixed heritable differences from others). For the moment, caution should be observed, for two reasons: (1) we have closely examined wild buffaloes only in Yala: those in other areas in Sri Lanka, if they still exist, may differ; (2) On the mainland, while several wild populations of B. a. fulvus (in Kaziranga, Manas and elsewhere in Assam) are well-known, and are consistent in their possession of white markings, much less is known of the other two subspecies, although limited evidence does suggest that they too are white-marked. Until the evidence is more complete, therefore, we should refer to the Sri Lankan wild buffalo as Bubalus arnee migona, while bearing in mind that it may ultimately have to be upgraded to species rank.

Postscript: "About seventy years ago", wrote Deraniyagala (1953), "wild buffaloes abounded in all forests of the low country, but today most of them have interbred with domestic stock. The relatively purest herds are restricted to Yala Game Sanctuary, but much vigilance will be necessary of this remnant is to be kept free from domestic animals which are now encroaching upon this once inaccessible area" (Deraniyagala 1953:27). This assessment remains true today (Buchholtz, 1988).
It is perhaps not completely unexpected that there should be still some pure-bred wild stock remaining, because a feral bull would have little or no chance of dominating a wild one, and would perhaps even be dominated by a wild cow; one would then expect, on theoretical grounds, that even hybrid cows would mate only with wild bulls, so that each backcrossed generation would be gradedup. Nonetheless, action should be taken to prevent more domestic stock from entering the National Park and joining those already there; and to somehow get rid of the feral and backcrossed animals now living permanently wild. Considering that there is a widespread appreciation of the value of wild "blood" in domestic stock (for example, Heinen, 2002), obviously backcrossed animals could be sold off to local herders. There is still a good chance of preserving Bubalus arnee migona in a relatively pure state, as part of Sri Lanka's wild heritage.

\section{Literature cited}

Ashby, K. R. and C. Santiapillai, 1983. The ecology of free-living water buffalo (Bubalus bubalis L.) in Sri Lanka and with particular reference to Ruhuna National Park. Tigerpaper, 10: 20-26.

Barker, J. S. F., S. S.Moore, D. J. S. Hetzel, D. Evans, S. G. Tan and K. Byrne, 1997. Genetic diversity of Asian water buffalo (Bubalus bubalis): microsatellite variation and a comparison with protein-coding loci. Animal Genetics, 28: 103-115.

Bongso, T. A., W. L. J. S. Kumaratileke and V. Buvanendran. 1977. The karyotype of the indigenous buffalo (Bubalus bubalis) of Sri Lanka. Ceylon Veterinary Journal, 25: 9-11.

Buchholtz, C., 1988. Rinder. Grzimeks Tierleben: Säugetiere, 5: 360-417. Munich: Kindler Verlag.

Cockrill, W. R., 1974. The buffaloes of Sri Lanka. In: W. R.Cockrill (Ed.). The Husbrandry and Health of the Domestic Buffalo. Rome: Food and Agriculture Organization of the United Nations. 629-635

Deraniyagala, P. E. P., 1952. Some Sinhala combative, field and aquatic sports and games. Spolia Zeylanica, 25: 179- 215.

Deraniyagala, P. E. P., 1953. The wild buffalo of Ceylon, a new subspecies. Spolia Zeylanica, 27: 103-105. 
Eisenberg, J. F. and G. M. McKay, 1970. An annoted checklist of the recent mammals of Ceylon with keys to the species. Ceylon Journal of Science, 8: 69-99.

Ellerman, J. R. and T. C. S. Morrison-Scott, 1951. Checklist of Palaearctic and Indian mammals. London: Trustees of the British Museum. 383.

Flamand, J. R. B., D. Vankan, K. P. Gairhe, H. Duong and J. S. F. Barker, 2003. Genetic identification of wild Asian water buffalo in Nepal. Animal Conservation, 6: 265-270.

Groves, C. P., 1996. The taxonomy of the Asian wild buffalo from the Asian mainland. Zeitschrift für Saugetierkunde, 61: 327-338.

Heinen, J. T., 2002. Phenotypic and behavioural characteristics used to identify wild buffalo Bubalus bubalis from feral backcrosses in Nepal. Journal of Bombay Natural History Society, 99: 173-183.

Hemmer, H., 1983 (trans.1990). Domestication: the Decline of Environmental Appreciation. Cambridge: Cambridge University Press.

Herre, W. and M. Röhrs, 1990. Haustiere Zoologisch Gesehen. $2^{\text {nd }}$ edition. Stuttgart: Gustav Fischer.

Kelaart, E. F., 1852. Prodromus Faunae Zeylanicae. R. Pethiyagoda and K. ManamendraArachchi (Eds.). Wildlife Heritage Trust, Colombo, 342.

Phillips, W. W. A., 1980. Manual of the mammals of Sri Lanka. $2^{\text {nd }}$.ed. Wildlife and Nature Protection Society of Sri Lanka, Colombo. 


\section{PLATE 10}

\section{Canonical Discriminant Functions}

biorb + horn measurements

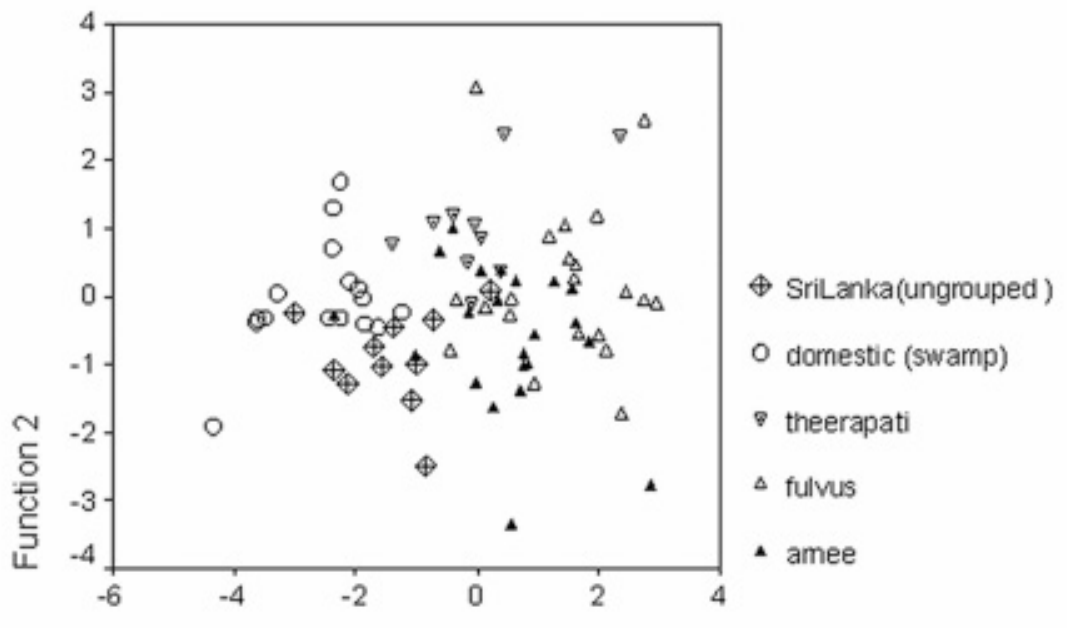

Function 1

Fig. 01: Discriminant analysis using horn measurements and biorbital breadth. DF1 accounts for $86.6 \%$ of the total variance; DF2, for $11.7 \%$. Structure Matrix

\begin{tabular}{crrr} 
& \multicolumn{3}{c}{ Function } \\
BIORB & 1 & 2 & 3 \\
BASEOUTE & .776 & -.117 & .322 \\
TIPTIP & .540 & .477 & .046 \\
BASETIP & .539 & .751 & .158 \\
SPAN & .423 & .623 & .068 \\
& & .603 & -.083
\end{tabular}

\section{Canonical Discriminant Functions}

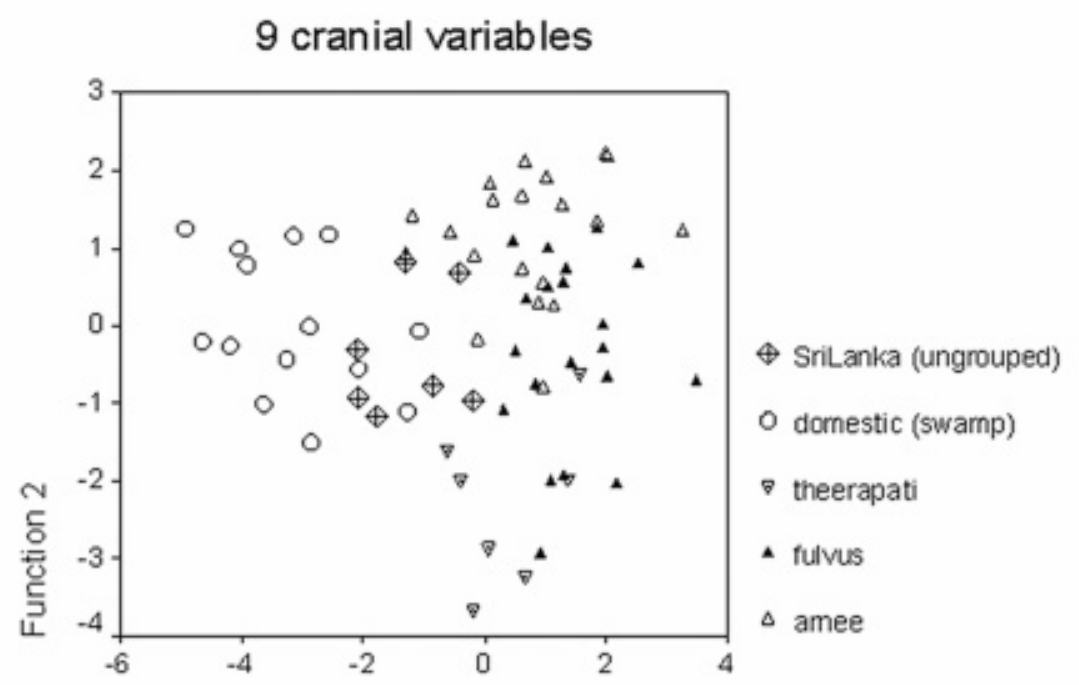

Function 1

Fig. 02: Discriminant analysis using skull measurements. DF1 accounts for $72.5 \%$ of the total variance; DF2, for $24.6 \%$. Structure Matrix:

$\begin{array}{crrr} & & \text { Function } & \\ \text { OCCGT } & 1 & 2 & 3 \\ \text { NASL } & .756 & . .211 & -.119 \\ \text { BIORB } & .752 & .270 & -.212 \\ \text { GTL } & .706 & .038 & -.423 \\ \text { PO } & .550 & .079 & -.209 \\ \text { BETWBASE } & .465 & .025 & .021 \\ \text { BASENASA } & .376 & .393 & .096 \\ \text { OCCL } & .260 & -.037 & .025 \\ \text { BRNASANT } & .453 & -.168 & -.083 \\ & & \end{array}$




\section{PLATE 11}

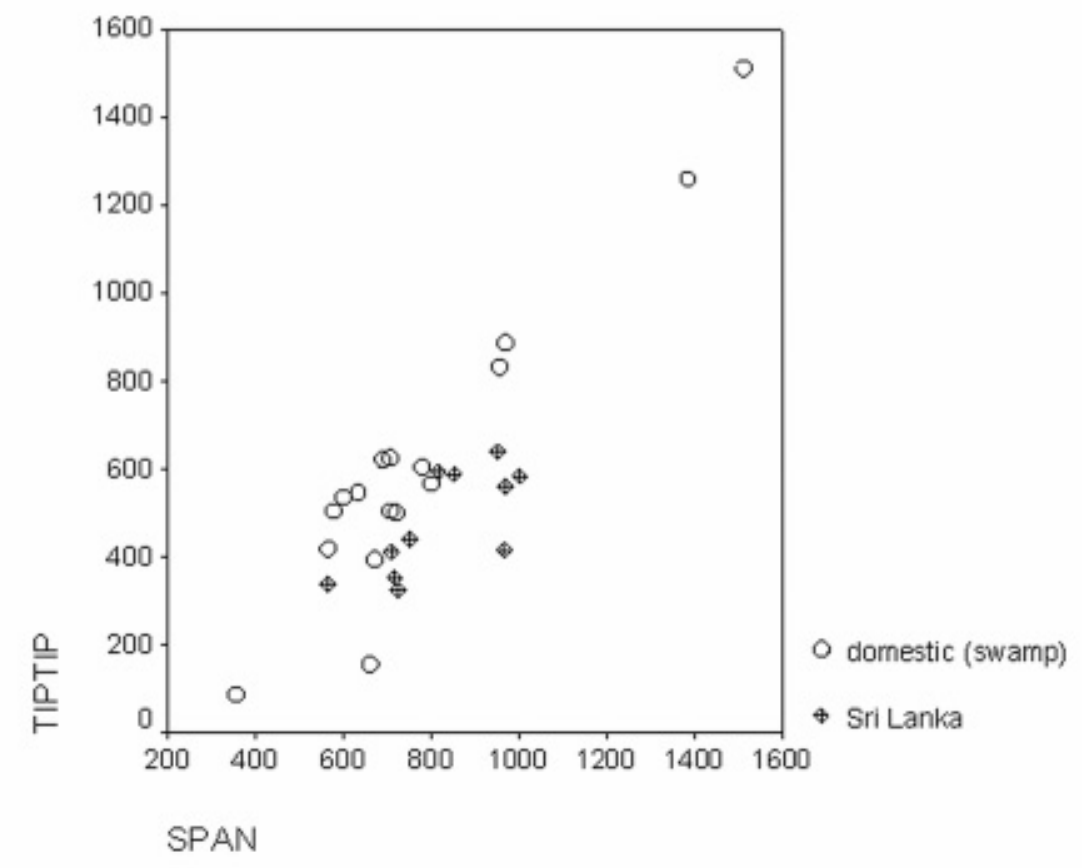

Fig. 03: Horn shape (tip-to-tip vs. total span), comparing domestic swamp and Sri Lankan wild buffaloes

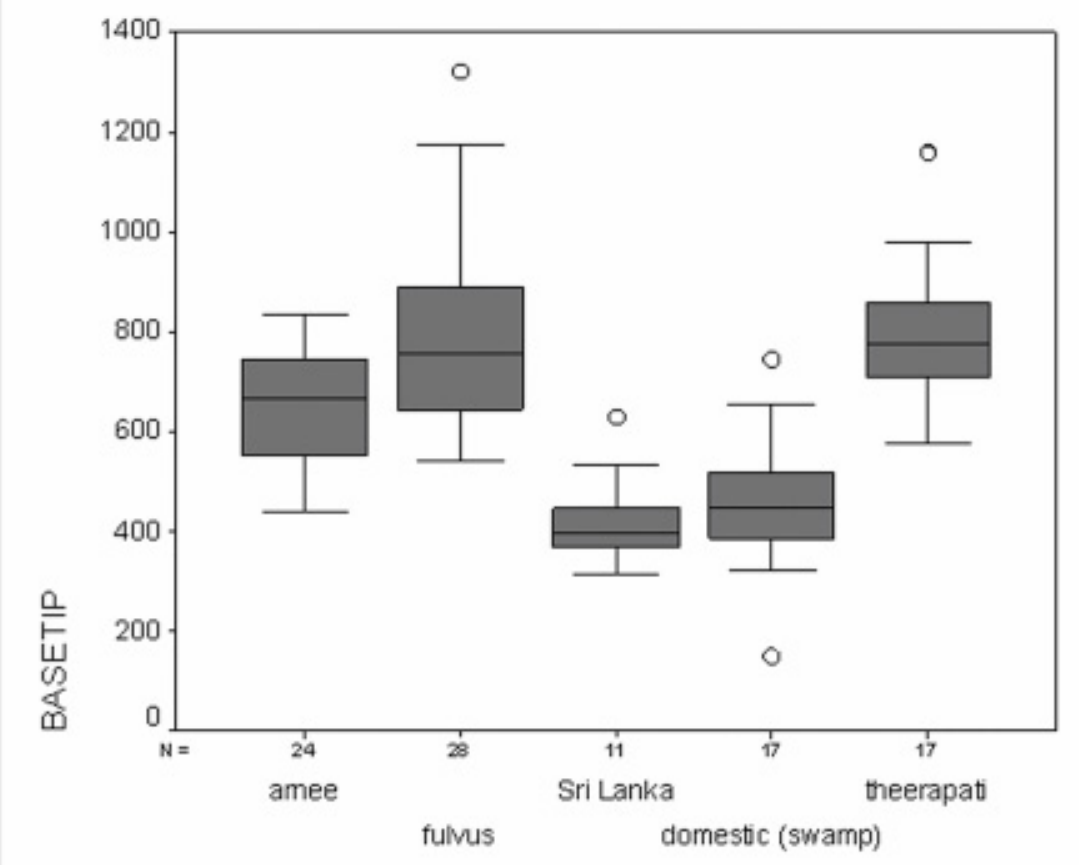

Fig. 04a: Horn base to tip distance in wild and domestic (swamp) buffaloes 


\section{PLATE 17}

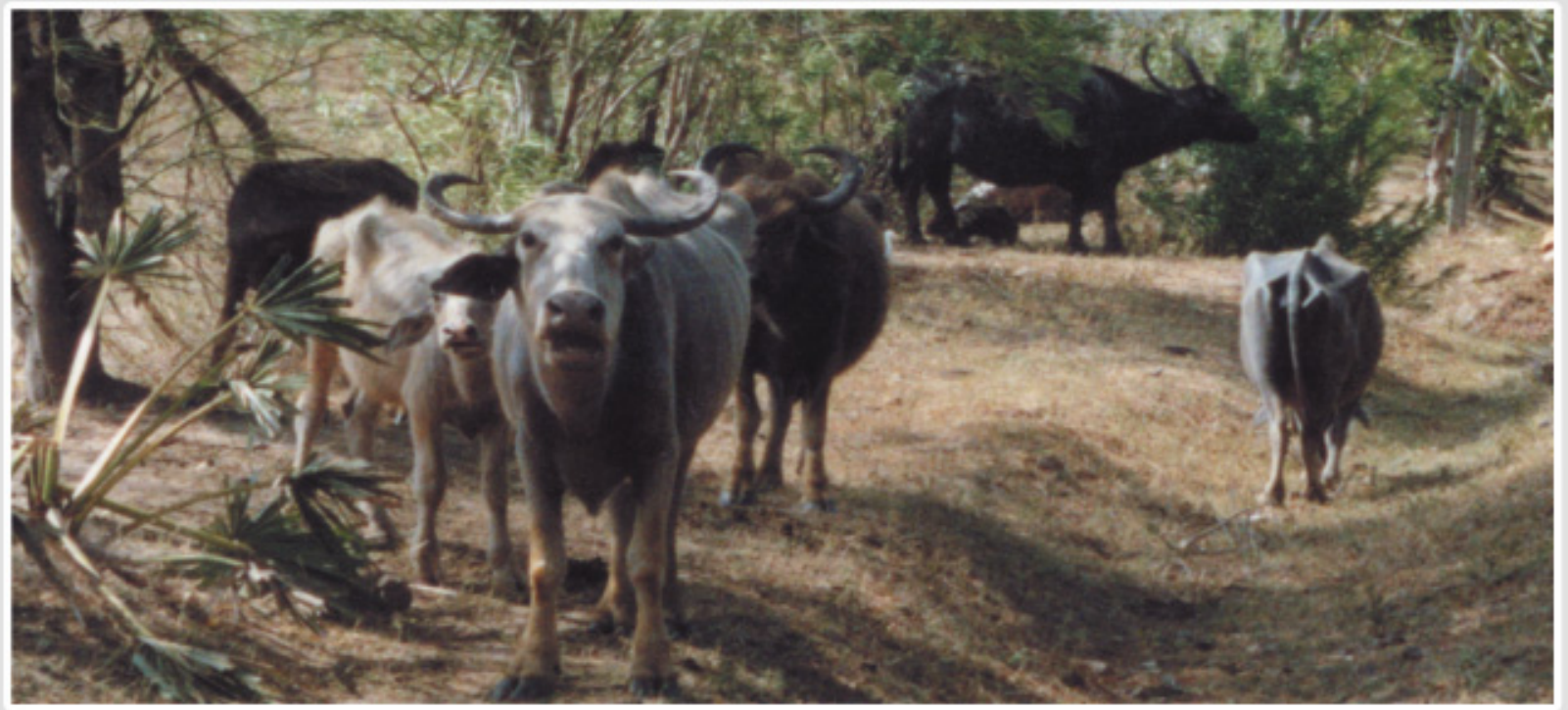

Fig. 14: Part of a group of domestic buffaloes near Tissamaharana, near Yala National Park
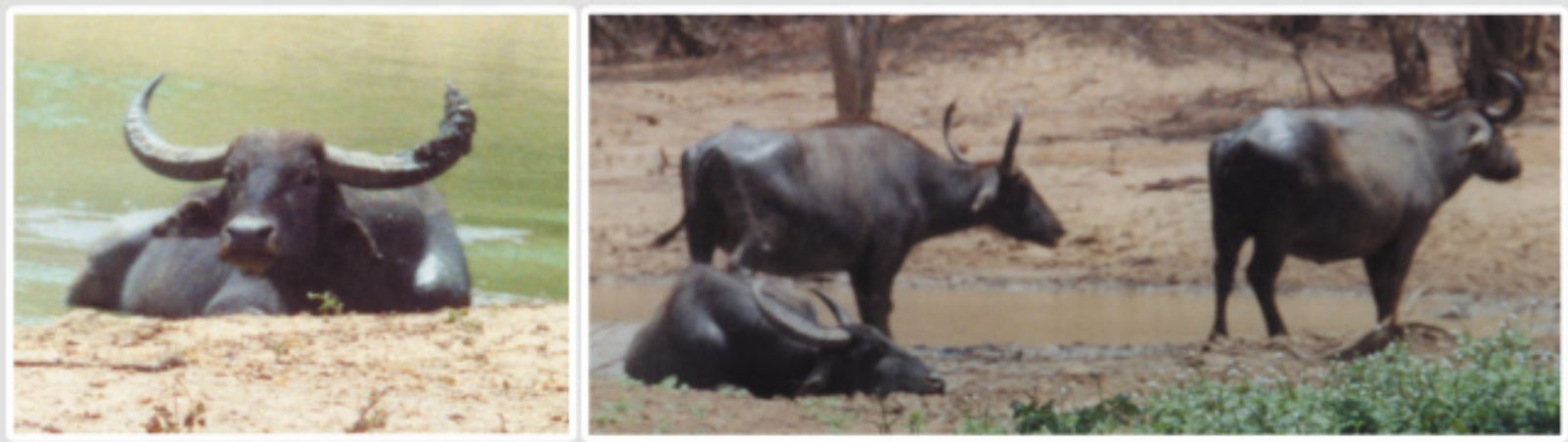

Fig. 15: Wild bull in Yala National Park, Fig. 16: Group of 3 in Yala NP, The bull (standing, right) and one of the cows interpreted as wild-type (lying down) are of wild-type; the other cow (standing, left) is interpreted as mixed

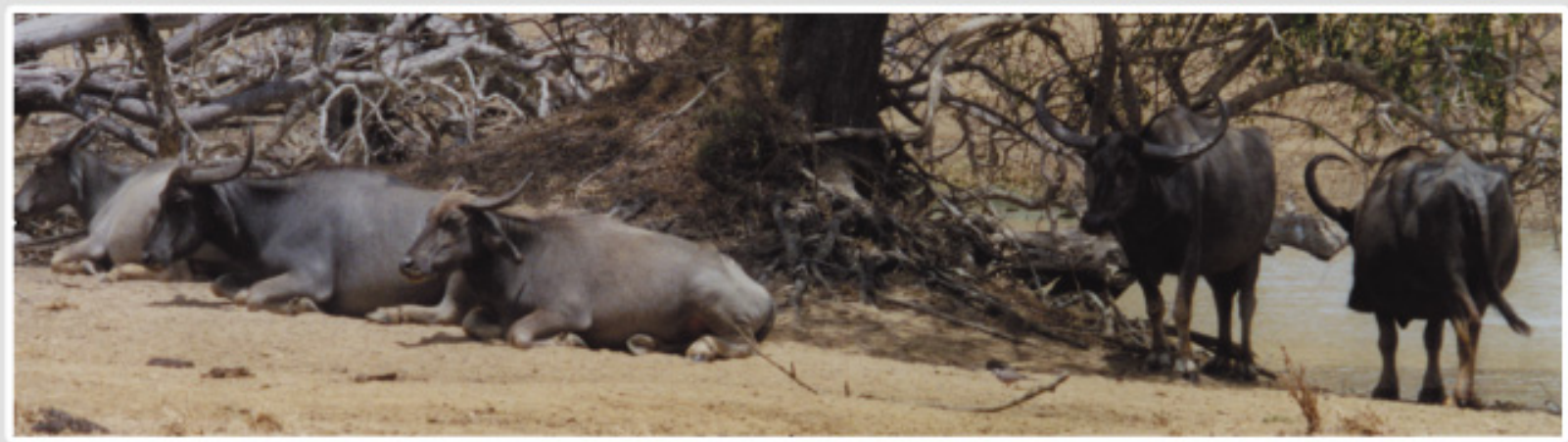

Fig. 17: Wild cows and calves in Yala National Park, domestic-type 